\title{
Istotny pogląd Prezesa UOKiK jako element postępowania sądowego
}

\section{Wprowadzenie}

Ustawą z dnia 5 sierpnia 2015 r. o zmianie ustawy o ochronie konkurencji i konsumentów oraz niektórych innych ustaw ${ }^{1}$ ustawodawca zdecydował się przyznać Prezesowi Urzędu Ochrony Konkurencji i Konsumentów (Prezes UOKiK lub Prezes Urzędu) kompetencję do wydawania istotnych dla toczących się przed sądami spraw poglądów. Zgodnie z założeniami projektodawcy wspomniana instytucja miała na celu zapewnienie „transferu wiedzy i doświadczeń z UOKiK do sądów powszechnych"2.

Niniejszy artykuł jest analizą instytucji istotnego poglądu w kontekście dotychczasowej praktyki sądów oraz Prezesa $\mathrm{UOKiK}^{3}$. Jego tematem są w szczególności pojawiające się po ponad roku funkcjonowania instytucji zagadnienia proceduralne związane zarówno z wydawaniem poglądów, jak i ich rozpatrywaniem przez sądy. Jednoznaczne rozstrzygnięcie tych problemów w ocenie autora ma kluczowe znaczenie z punktu widzenia celu, jaki przyświecał ustawodawcy przy wprowadzaniu omawianej regulacji do polskiego systemu prawnego. Artykuł jest także odpowiedzią na pytanie dotyczące charakteru prawnego istotnego poglądu. Co ciekawe, zarówno przez praktyków, jak i sądy

${ }^{1}$ Dz.U. 2015, poz. 1634, dalej „u.o.k.k.”.

${ }^{2}$ Druk sejmowy nr 3662/VII kadencja z 10 VII 2015 r., s. 17.

${ }^{3} \mathrm{Z}$ informacji znajdujących się na stronie https://www.uokik.gov.pl/istotny_poglad_w_sprawie.php (dostęp: 21 I 2018) wynika, że na dzień 17 I 2018 r. Prezes UOKiK wydał 268 poglądów. 
pogląd Prezesa Urzędu bywa traktowany jako środek dowodowy ${ }^{4}$, co nie wydaje się słusznym stanowiskiem. Powyższe ustalenia poprzedza analiza przesłanek określonych $\mathrm{w}$ art. 31d u.o.k.k., których spełnienie warunkuje wydanie istotnego poglądu w konkretnej sprawie.

\section{Przesłanki wydania istotnego dla sprawy poglądu}

Zgodnie z art. 31d u.o.k.k., jeżeli Prezes UOKiK uzna, że przemawia za tym interes publiczny, przedstawia sądowi istotny dla sprawy pogląd w sprawach dotyczących ochrony konkurencji i konsumentów. W ocenie autora z przywołanego przepisu wynikają cztery zasadnicze przesłanki wydania przez Prezesa UOKiK poglądu. Po pierwsze, za wydaniem poglądu musi przemawiać interes publiczny; po drugie, pogląd, który miałby być ewentualnie przedstawiony, winien być istotny dla toczącej się sprawy; po trzecie, pogląd może zostać wydany dla sprawy, która zawisła przed sądem; po czwarte, przedmiot sprawy winien dotyczyć szeroko rozumianej ochrony konkurencji i konsumentów.

Należy zgodzić się z poglądem, że przesłanka interesu publicznego nie jest pojęciem jednolitym i stałym, a w konsekwencji winna być dla każdej sprawy konkretyzowana odrębnie ${ }^{5}$. W literaturze i orzecznictwie podejmowane sa próby wypełnienia tej klauzuli generalnej treścią ${ }^{6}$ Wskazuje się przy tym dwie przeciwstawne linie orzecznicze. Pierwsza ma kłaść nacisk na element ilościowy, tj. działanie w interesie publicznym ma oznaczać działanie w interesie szerszego kręgu podmiotów. Druga z kolei ma kłaść nacisk na aspekt "jakościowy" i utożsamiać

${ }^{4}$ Sąd Okręgowy (SO) w Poznaniu w wyroku z 1 VI 2017 r. (sygn. XVIII C 94/17, Portal Orzeczeń Sądów Powszechnych, dostęp: 21 I 2018) oddalił wniosek pozwanego o wezwanie Prezesa UOKiK do przedstawienia pisemnego poglądu istotnego dla sprawy, wskazując, że był to dowód zbędny dla rozstrzygnięcia i zmierzałby do przedłużenia postępowania.

${ }^{5} \mathrm{~W}$ tym zakresie zob. m.in. A. Stawicki, E. Stawicki, Komentarz do art. 1 ustawy o ochronie konkurencji i konsumentów, w: Ustawa o ochronie konkurencji i konsumentów. Komentarz, pod red. A. Stawickiego, E. Stawickiego, Warszawa 2016, s. 37. Stanowisko to uznać należy za ugruntowane w orzecznictwie Prezesa UOKiK (por. m.in. decyzję Prezesa UOKiK z 8 VIII 2017 r., Nr DOK-1/2017). Odmiennie K. Kohutek, Komentarz do art. 1 ustawy o ochronie konkurencji i konsumentów, w: K. Kohutek, M. Sieradzka, Ustawa o ochronie konkurencji i konsumentów. Komentarz, Warszawa 2014, s. 57-58.

${ }^{6}$ Zob. m.in. A. Stawicki, E. Stawicki, op. cit., s. 37 i n.; K. Kohutek, op. cit., s. 57 i n.; wyrok Sądu Najwyższego (SN) z 5 VI 2008 r., sygn. III SK 40/07, Legalis nr 175656, i orzecznictwo tam wskazane. Por. również wyrok SN z 20 IV 2017 r., sygn. III SK 21/16, LEX nr 2310099. 
działanie w interesie publicznym z ochroną mechanizmów konkurencji, niejako niezależnie od kręgu uczestników rynku, który potencjalnie może być podmiotem owych mechanizmów ${ }^{7}$. W ocenie autora, w zależności od sprawy, o istnieniu interesu publicznego do podjęcia działań przez Prezesa Urzędu może świadczyć zarówno istnienie znacznej liczby podmiotów potencjalnie zainteresowanych podjęciem przez niego działań (np. w przypadku, gdy praktyka narusza interesy dużej liczby uczestników rynku), jak i wzgląd na ochronę mechanizmów uczciwej konkurencji, wolnej od praktyk godzących w pozostałych uczestników rynku (w sytuacji, gdy faktyczne naruszenie interesów podmiotów ma tylko potencjalny charakter).

Odnosząc powyższe do kompetencji Prezesa UOKiK do wydania istotnego dla sprawy poglądu, podkreślić należy, że Prezes UOKiK zobligowany jest każdorazowo do weryfikacji, czy za jego zaangażowaniem w sprawę przemawia interes publiczny, rozumiany w wyżej opisany sposób. Co istotne, jak się wydaje, ma on przyznaną w tym zakresie stosunkowo dużą swobodę, ograniczoną jedynie zakazem angażowania się w sprawy o stricte indywidualnym charakterze (tj. nierzutującym w żaden sposób, choćby pośredni, na sytuację pozostałych uczestników rynku). Wskazać bowiem należy, że ocena występowania interesu publicznego dla przedstawienia istotnego dla sprawy poglądu pozostawiona została wyłącznie wydającemu go Prezesowi UOKiK ${ }^{8}$.

$\mathrm{Z}$ art. 31d u.o.k.k. wynika, że przedstawiany sądowi przez Prezesa UOKiK pogląd winien być dla danej sprawy istotny. $W$ ocenie autora przesłankę istotności należy rozumieć w ten sposób, że pogląd powinien mieć znaczenie dla rozstrzygnięcia danej sprawy ${ }^{9}$ Nie może on jednak dotyczyć dowolnego jej aspektu. Pogląd winien być wydawany jedynie w zakresie kwestii obiektywnie istotnych dla jej rozstrzygnięcia. Zagadnienia nieistotne z punktu widzenia rozstrzygnięcia nie powinny być jego przedmiotem.

Odnosząc powyższe do aktualnej praktyki Prezesa UOKiK, należy zwrócić uwagę, że wydawane poglądy dotyczą w przeważającym

${ }^{7}$ Por. A. Stawicki, E. Stawicki, op. cit., s. 37-42; K. Kohutek, op. cit., s. 58-63, oraz orzecznictwo i literatura tam wskazane.

${ }^{8} \mathrm{Z}$ art. 31d u.o.k.k. wprost wynika, że Prezes UOKiK wydaje pogląd, jeżeli uzna, że przemawia za tym interes publiczny (decyzja w tym zakresie została pozostawiona uznaniu Prezesa UOKiK).

${ }_{9}^{9}$ Por. M. Błachucki, Komentarz do art. 31(d) ustawy o ochronie konkurencji i konsumentów, w: Ustawa o ochronie konkurencji i konsumentów..., pod red. A. Stawickiego, E. Stawickiego, s. 758 . 
zakresie niedozwolonych postanowień stosowanych przez przedsiębiorców we wzorcach umownych wykorzystywanych w relacjach $\mathrm{z}$ konsumentami ${ }^{10}$. Z treści uzasadnień poglądów wynika, że wnioski składane o ich wydanie bywają formułowane w sposób niezwykle ogólny. Wnioskodawcy domagają się np. wyrażenia poglądu w przedmiocie abuzywności wszystkich postanowień zawartych w umowie będącej przedmiotem toczącej się przed sądem sprawy bądź postanowień, które nie mają żadnego znaczenia dla sprawy ${ }^{11}$. W takich sytuacjach, o ile istnieje interes publiczny w przedstawieniu poglądu, uznaniu Prezesa UOKiK pozostawiony jest wybór postanowień, których ocena $w$ jego opinii może być istotna dla rozstrzygnięcia danej sprawy. W tym zakresie Prezes Urzędu nie jest związany kierowanym do niego wnioskiem ${ }^{12}$.

W świetle art. 31d u.o.k.k. nie może ulegać wątpliwości, że istotny pogląd może zostać wydany jedynie dla sprawy toczącej się przed sądem. Wydaje się, że omawiany warunek można interpretować w dwojaki sposób. Po pierwsze, oczywiste jest, że aby pogląd mógł być przez Prezesa UOKiK wydany, sprawa musi być na etapie postępowania sądowego. Ustawa za niedopuszczalne uznaje zatem wydanie poglądu zarówno na etapie przedsądowym (np. w toku przedsądowej mediacji lub w trakcie postępowania reklamacyjnego), jak i po jej zakończeniu ${ }^{13}$. Wydaje się przy tym zasadne twierdzenie, że o wszczęciu postępowania sądowego i tym samym aktualizacji uprawnienia Prezesa UOKiK do przedstawienia istotnego dla sprawy poglądu możemy mówić z chwilą skutecznego

${ }^{10}$ Por. poglądy opublikowane na stronie https://uokik.gov.pl/istotny_poglad_w_sprawie.php (dostęp: 21 I 2018).

${ }_{11}$ Zob. pogląd Prezesa UOKiK z 24 I 2017 r. wydany dla sprawy II C 340/16 toczącej się przed SO w Warszawie, sygn. RPZ-644-504/16/PG, https://uokik.gov.pl/istotny_poglad_w_sprawie.php (dostęp: 21 I 2018) oraz pogląd Prezesa UOKiK z 10 XI 2016 r. wydany dla sprawy XXVII Ca 3477/17 toczącej się przed SO w Warszawie, sygn. RPZ644-502/16/PG, https://uokik.gov.pl/istotny_poglad_w_sprawie.php (dostęp: 21 I 2018).

${ }^{12} \mathrm{~W}$ literaturze, jak się wydaje, istnieje jednolite stanowisko, zgodnie z którym ewentualne wydanie poglądu ma charakter fakultatywny i decyzja w tym zakresie pozostawiona jest uznaniu Prezesa UOKiK. Zob.: M. Błachucki, op. cit., s. 755; J. Szczygieł, Nowa prerogatywa Prezesa UOKiK do przedstawienia istotnego pogladu w sprawie, w: Prawo konsumenckie w praktyce, pod red. M. Czarneckiej, T. Skocznego, Warszawa 2016, s. 136.

${ }^{13} \mathrm{~W}$ tym zakresie w przypadku postępowania cywilnego kluczowe znaczenie będzie miał moment zamknięcia rozprawy. Wskazać bowiem należy, że wydając wyrok, za podstawę rozstrzygnięcia sąd każdorazowo bierze właśnie stan rzeczy istniejący w chwili zamknięcia rozprawy (art. 316 \& 1 Ustawy z dnia 17 XI 1964 r. Kodeks postępowania cywilnego - tekst jedn. Dz.U. 2016, poz. 1822 ze zm., dalej „k.p.c.”). Wydaje się zatem, że przedstawienie poglądu po tej chwili jest bezprzedmiotowe. 
wniesienia pisma procesowego inicjującego to postępowanie. Dla spraw cywilnych będzie to co do zasady chwila wniesienia pozwu lub wniosku, w przypadku spraw sądowoadministracyjnych moment wniesienia skargi ${ }^{14}$, natomiast dla spraw karnych wiązać będzie się to zazwyczaj $\mathrm{z}$ wniesieniem aktu oskarżenia.

Wydaje się, że z punktu widzenia omawianej przesłanki nie ma przeszkód, aby pogląd mógł być przedstawiony dla sprawy, której postępowanie zostało zawieszone. Można mieć jednak wątpliwości, czy w takiej sytuacji spełnione są przesłanki występowania interesu publicznego w przedstawieniu poglądu oraz istotności poglądu dla rozstrzyganej sprawy. Wskazać bowiem należy, że w perspektywie zawieszonej sprawy jest jej ewentualne umorzenie w przypadku spełnienia się ustawowych przesłanek (np. w braku podjęcia postępowania w określonym ustawą terminie). Mając na względzie, że w przypadku umorzenia uprzednio zawieszonej sprawy pogląd Prezesa UOKiK nie będzie miał dla niej żadnego znaczenia, postulować należy powstrzymanie się przez Prezesa UOKiK od wydawania poglądów w sprawach zawieszonych do chwili ich formalnego podjęcia.

Aby można było sformułować pogląd, sprawa winna toczyć się przed sądem. Wykładnia autentyczna sugerowałaby, że Prezes UOKiK ma możliwość przedstawiania poglądów jedynie sądom rejonowym, okręgowym i apelacyjnym (założeniem projektodawcy było zapewnienie transferu wiedzy i doświadczeń z UOKiK do sądów powszechnych). Wydaje się jednak, że treść art. 31d u.o.k.k. nie pozwala na tego rodzaju zawężenie kręgu adresatów poglądów. W tym zakresie, w ocenie autora, pierwszeństwo należy dać wykładni językowej, z której w sposób niebudzący wątpliwości wynika, że Prezes UOKiK może przedstawić pogląd istotny dla sprawy każdemu sądowi, w tym również Sądowi Najwyższemu15 oraz sądom administracyjnym ${ }^{16}$. Odmiennie należy ocenić możliwość przedstawienia poglądu Trybunałowi Konstytucyjnemu (TK). Biorąc pod uwagę, że TK jest odrębnym od sądów organem konstytucyjnym

\footnotetext{
${ }^{14}$ Por. postanowienie Naczelnego Sądu Administracyjnego z 29 VI 2016 r., sygn. I FZ 156/16, Legalis nr 1537324.

${ }^{15}$ Do tej pory Prezes UOKiK tylko raz przedstawiał pogląd Sądowi Najwyższemu. Zob. pogląd Prezesa UOKiK z dnia 25 VII 2017 r. wydany dla sprawy IV CSK 667/16 toczącej się przed SN, sygn. RLO-644-13/17/RB, https://uokik.gov.pl/istotny_poglad_w_ sprawie.php (dostęp: 21 I 2018).

${ }^{16}$ Należy równocześnie zgodzić się z poglądem, że możliwość przedstawienia poglądu nie istnieje w sytuacji, gdy Prezes UOKiK jest stroną toczącego się postępowania. Tak J. Szczygieł, op. cit., s. 135.
} 
państwa, uznać należy, że Prezes UOKiK nie posiada kompetencji do przedstawiania poglądów dla toczących się przed nim spraw.

Zgodzić się natomiast należy z poglądem, że Prezes UOKiK może przedstawić pogląd sądom powszechnym zarówno w toku spraw cywilnych, jak i karnych ${ }^{17}$. Stwierdzić bowiem należy, że we wszystkich wskazanych rodzajach spraw mogą się pojawić zagadnienia dotyczące ochrony konkurencji i konsumentów, w ramach których Prezes Urzędu mógłby podzielić się swoją specjalistyczną wiedzą i doświadczeniem.

W ocenie autora brak jest również przeciwwskazań, aby pogląd mógł być przedstawiony przez Prezesa UOKiK sądom polubownym (tj. chociażby stałym sądom polubownym działającym przy wojewódzkich inspektoratach inspekcji handlowej, działającym na podstawie art. 37 i n. Ustawy z dnia 15 grudnia 2000 r. o Inspekcji Handlowej ${ }^{18}$ ). Wydaje się, że stanowisko Prezesa UOKiK w tego typu sprawach może odegrać istotną rolę zwłaszcza w sytuacji, gdy strony są w błędzie co do wykładni aktualnie obowiązujących regulacji. Jednocześnie, przedstawiając pogląd na tym etapie sprawy, Prezes UOKiK dzięki swojemu autorytetowi może nie tylko pomóc stronom dojść do konsensusu, ale również wnieść swój wkład we wzmacnianie polskiego systemu alternatywnych metod rozstrzygania sporów.

Za truizm należy uznać stwierdzenie, że o poglądzie możemy mówić jako o istotnym dla sprawy jedynie w sytuacji, gdy zawiera on treści o charakterze specjalistycznym.

Wbrew poglądom wyrażonym w doktrynie nie sposób ograniczać kompetencję Prezesa UOKiK do przedstawienia istotnego poglądu jedynie dla spraw sądowych o ochronę konkurencji i konsumentów ${ }^{19}$. Z art. 31d

${ }^{17}$ Por. M. Błachucki, op. cit., s. 755. Odmiennie: A. Piszcz (Komentarz do art. 31(d) ustawy o ochronie konkurencji i konsumentów, w: Ustawa o zmianie ustawy o ochronie konkurencji $i$ konsumentów z 5.8.2015 r. Komentarz, pod red. A. Piszcz, M. Namysłowskiej, Warszawa 2016, s. 87), która stoi na stanowisku, iż art. 31d u.o.k.k. powinien być interpretowany nie w ten sposób, że Prezes UOKiK może przedstawiać sądowi w wąsko rozumianych sprawach o ochronę konkurencji czy konsumentów istotny pogląd w każdej kwestii, lecz w ten sposób, że Prezes UOKiK może przedstawiać sądowi w zasadzie we wszelkich sprawach cywilnych w rozumieniu art. 1 k.p.c. istotny pogląd o wynikłych w sprawie kwestiach dotyczących ochrony konkurencji lub ochrony konsumentów. Należy zwrócić uwagę, że choć autorka podejmuje próbę szerszego ujęcia przesłanki „spraw dotyczących ochrony konkurencji i konsumentów", to ogranicza jednocześnie możliwość przedstawienia poglądu wyłącznie do spraw cywilnych.

18 Tekst jedn. Dz.U. 2017, poz. 1063 ze zm.

${ }^{19} \mathrm{~W}$ doktrynie podejmowane są próby kategoryzowania spraw sądowych i poszukiwania tych, które są sprawami z zakresu ochrony konkurencji i konsumentów. W świetle 
u.o.k.k. wynika bowiem, że Prezes UOKiK ma prawo do wypowiadania się „W sprawach dotyczących ochrony konkurencji i konsumentów". Z tego należy wnioskować, że ma kompetencję do przedstawienia poglądu we wszelkiego rodzaju sprawach sądowych, ale jedynie w zakresie zagadnień i problemów związanych z ochroną konkurencji i konsumentów (słowo "sprawa” w tym kontekście należy intepretować jako zespół okoliczności, które są przedmiotem czyjegoś zainteresowania, a nie jako postępowanie toczące się przed sądem ${ }^{20}$ ). Kluczowe dla podjęcia decyzji o przedstawieniu istotnego poglądu jest zatem to, czy istotne z punktu widzenia rozstrzygnięcia zagadnienie, które ma być przedmiotem istotnego poglądu, dotyczy szeroko rozumianej ochrony konkurencji i konsumentów.

\section{Procedura wydania istotnego poglądu przez Prezesa UOKiK}

Ustawa o ochronie konkurencji i konsumentów nie zawiera regulacji co do procedury wydawania istotnych poglądów przez Prezesa UOKiK. Uznać zatem należy, że w zakresie nieuregulowanym w u.o.k.k., zgodnie z art. 83 tej ustawy, znajdą tu zastosowanie przepisy Ustawy z dnia 14 czerwca 1960 r. Kodeks postępowania administracyjnego ${ }^{21}$.

Na wstępie wskazać należy, że u.o.k.k. w art. 31d nie reguluje tego, czy pogląd wydawany jest $z$ urzędu czy też na wniosek podmiotu zainteresowanego w jego wydaniu. Należy się zatem zgodzić ze stanowiskiem, że może on być wydany zarówno na wniosek, jak i z inicjatywy samego Prezesa UOKiK ${ }^{22}$. Uwzględniając to, że dla wydania poglądu niezbędna jest wiedza w zakresie toczącej się sprawy sądowej, uznać należy, że poglądy wydawane z urzędu będą stanowiły rzadkość ${ }^{23}$.

art. 31d u.o.k.k. tego rodzaju zabiegi interpretacyjne należy uznać za zbędne, gdyż potencjalnie każda sprawa może dotykać zagadnień z zakresu ochrony konkurencji i konsumentów. Por. J. Szczygieł, op. cit., s. 131-132; A. Piszcz, op. cit., s. 85-87; M. Błachucki, op. cit., s. 755-756.

${ }^{20}$ Por. Słownik języka polskiego PWN, t. P-Ś, pod red. S. Dubisza, Warszawa 2006, s. $1347-1348$.

${ }^{21}$ Tekst jedn. Dz.U. 2017, poz. 1257 ze zm., dalej „k.p.a.”.

22 Por. J. Szczygiel, op. cit., s. 135. Odmiennie A. Piszcz (op. cit., s. 84), która stoi na stanowisku, że pogląd istotny dla sprawy może zostać przedstawiony z inicjatywy sądu albo z własnej inicjatywy Prezesa UOKiK, nie wyjaśnia jednak szerzej swojego stanowiska w tym zakresie. Odmiennie również M. Błachucki (op. cit., s. 758), który stoi na stanowisku, że pogląd może być przedstawiony tylko z własnej inicjatywy Prezesa UOKiK.

${ }^{23}$ Analiza poglądów udostępnionych na stronie Urzędu pozwala twierdzić, że dotychczas wszystkie z nich zostały wydane na wniosek zainteresowanych podmiotów, przede wszystkim stron toczących się postępowań, ale również sądów. 
W świetle art. 31d u.o.k.k. nie może ulegać wątpliwości, że Prezes UOKiK, wydając pogląd, działa w zakresie uznania administracyjnego. Wynika to wprost z powołanego przepisu, zgodnie z którym „Prezes UOKiK wydaje pogląd, jeżeli uzna, że przemawia za tym interes publiczny". Oznacza to jednocześnie, że przy rozpatrywaniu ewentualnego wniosku o wydanie stanowiska Prezes UOKiK nie jest w żadnym zakresie nim związany ${ }^{24}$.

Należy w tym miejscu zwrócić uwagę, że UOKiK działa poprzez swoją centralę w Warszawie, delegatury w Bydgoszczy, Gdańsku, Katowicach, Krakowie, Lublinie, Łodzi, Poznaniu, Warszawie i Wrocławiu oraz laboratoria mu podległe (art. 33 ust. 1 u.o.k.k.). Nie budzi w tym kontekście wątpliwości, że centralnym organem administracji rządowej jest wyłącznie Prezes UOKiK, co wprost wynika z art. 29 ust. 1 u.o.k.k. Takiego statusu nie mają ani warszawska centrala, ani delegatury i laboratoria realizujące w praktyce zadania powierzone Prezesowi UOKiK ${ }^{25}$. Nie ma to jednak wpływu na faktyczną możliwość przekazania rozpoznania wpływających do Prezesa UOKiK wniosków o wydanie poglądu podległym mu jednostkom ${ }^{26}$. W tym kontekście wskazać wypada, że zgodnie z \& 2 pkt 9 Rozporządzenia Prezesa Rady Ministrów w sprawie właściwości miejscowej i rzeczowej delegatur Urzędu Ochrony Konkurencji i Konsumentów ${ }^{27}$ w zakresie swojej właściwości miejscowej do zadań delegatur należy przedstawianie sądowi istotnego dla sprawy poglądu w sprawach dotyczących ochrony konkurencji i konsumentów na podstawie art. 31d u.o.k.k. Niestety, samo Rozporządzenie nie precyzuje, co przesądza o ustaleniu właściwości miejscowej danej delegatury (tj. nie wskazuje, czy uwzględniać należy siedzibę lub adres zamieszkania wnioskodawcy czy siedzibę sądu). Powyższe uznać należy za lukę legislacyjną, uniemożliwiającą w praktyce określenie ścisłej właściwości miejscowej delegatur w zakresie przyznanej im generalnej kompetencji do wydawania istotnych dla spraw poglądów. W konsekwencji stwierdzić należy, że każdorazowe przekazanie delegaturze do rozpoznania wniosku o wydanie istotnego poglądu będzie wymagało

\footnotetext{
${ }^{24}$ Zob.: M. Błachucki, op. cit., s. 755; J. Szczygieł, op. cit., s. 136.

25 Por. wyrok Sądu Antymonopolowego z 13 VIII 2001 r., sygn. XVII Ama 95/00, Legalis nr 72470.

${ }^{26}$ Zgodnie z art. 33 ust. 4 u.o.k.k. delegatury UOKiK oprócz spraw należących do ich właściwości mogą załatwiać inne sprawy przekazane im przez Prezesa Urzędu.

${ }^{27}$ Tekst jedn. Dz.U. 2017, poz. 816 ze zm., dalej „Rozporządzenie”.
} 
sporządzenia przez Prezesa UOKiK odrębnego upoważnienia (ogólna delegacja w Rozporządzeniu jest w tym zakresie niewystarczająca).

Wniosek o przedstawienie poglądu, stanowiąc podanie w rozumieniu art. 63 k.p.a., winien zawierać co najmniej wskazanie osoby, od której pochodzi, jej adres i żądanie (art. $63 \S 2$ k.p.a.). O ile wniosek o wydanie poglądu składany jest przez pełnomocnika, powinno być do niego dołączone właściwie sformułowane pełnomocnictwo ${ }^{28}$ (art. 33 $\S 3$ k.p.a.) wraz z dowodem uiszczenia stosownej opłaty skarbowejej.

Niezależnie od wyżej wskazanych wymogów ustawowych wydaje się, że kierowany do Prezesa UOKiK wniosek o wydanie poglądu winien obligatoryjnie zawierać co najmniej informację o sądzie, przed którym prowadzona jest sprawa, dla której pogląd miałby być przedstawiony. Za niezbędny element wniosku trzeba również uznać określenie sygnatury sprawy. Należy zwrócić uwagę, że nieuwzględnienie danych wskazanych we wniosku w praktyce uniemożliwia wydanie poglądu.

Wobec faktu, że rozpoznanie wniosku o wydanie istotnego dla sprawy poglądu każdorazowo obliguje Prezesa UOKiK do zweryfikowania występowania przesłanek określonych $\mathrm{w}$ art. 31d u.o.k.k., zasadna wydaje się konstatacja, iż wnioskodawca w podaniu winien (1) podjąć próbę uzasadnienia, w czym jego zdaniem przejawia się interes publiczny

${ }^{28}$ Należy zaznaczyć, że standardowe pełnomocnictwo udzielone do reprezentowania strony postępowania cywilnego może być niewystarczające do złożenia wniosku o przedstawienie przez Prezesa UOKiK istotnego dla sprawy poglądu. Istotne jest bowiem, że zgodnie $z$ art. 91 k.p.c. pełnomocnictwo procesowe obejmuje z samego prawa: (1) umocowanie do wszystkich łączących się ze sprawą czynności procesowych, nie wyłączając powództwa wzajemnego, skargi o wznowienie postępowania i postępowania wywołanego ich wniesieniem, jako też wniesieniem interwencji głównej przeciwko mocodawcy; (2) wszelkich czynności dotyczących zabezpieczenia i egzekucji; (3) udzielenia dalszego pełnomocnictwa procesowego adwokatowi lub radcy prawnemu; (4) zawarcia ugody, zrzeczenia się roszczenia albo uznania powództwa, jeżeli czynności te nie zostały wyłączone w danym pełnomocnictwie; (5) odbioru kosztów procesu od strony przeciwnej. W konsekwencji, w przypadku gdy strona zwraca się z wnioskiem o przedstawienie poglądu bezpośrednio do Prezesa UOKiK (z pominięciem sądu rozpoznającego sprawę), nie można takiej czynności uznać za czynność procesową w rozumieniu k.p.c. W rezultacie do jej dokonania wymagane jest odrębne pełnomocnictwo do reprezentowania strony przed Prezesem UOKiK lub pełnomocnictwo procesowe o szerszym od ustawowego zakresie. Powyższe nie dotyczy wniosków o wydanie poglądów istotnych dla sprawy składanych w trybie art. 187 § 2 k.p.c. Wówczas bowiem pełnomocnik działa w ramach przyznanego umocowania procesowego.

${ }^{29}$ Szczegółowe zasady wnoszenia opłaty od złożenia dokumentu stwierdzającego udzielenie pełnomocnictwa lub prokury oraz od jego odpisu, wypisu lub kopii określone są w Ustawie z dnia 16 XI 2006 r. o opłacie skarbowej (tekst jedn. Dz.U. 2016, poz. 1827 ze zm.). 
w przedstawieniu poglądu dla danej sprawy, (2) określić zagadnienia z zakresu ochrony konkurencji i konsumentów, które winny być przedmiotem poglądu oraz (3) uprawdopodobnić, że stanowisko Prezesa UOKiK w zakresie tych zagadnień może mieć istotne znaczenie dla toczącej się przed sądem sprawy. Choć wyżej wskazane elementy wniosku mają charakter fakultatywny, to nie może ulegać wątpliwości, że ich wyczerpujące uzasadnienie w kierowanym do Prezesa UOKiK podaniu może przyczynić się do jego szybszego rozpoznania oraz w praktyce zwiększyć prawdopodobieństwo jego uwzględnienia.

Zważywszy, że Prezes UOKiK może przedstawić pogląd tylko w sytuacji, gdy dotyczy on zagadnień o charakterze istotnym dla rozstrzygnięcia danej sprawy, kluczowe wydaje się załączenie do wniosku materiału sprawy (w tym dotychczas składanych pism procesowych oraz dowodów), który umożliwiłby weryfikację tej przesłanki. Powyższe ma szczególne znaczenie dla spraw rozpoznawanych poza procedurą cywilną. Należy bowiem zwrócić uwagę, że zgodnie z art. $63^{5} \S 2$ k.p.c. na wniosek Prezesa UOKiK sąd udostępni mu akta sprawy w zakresie niezbędnym do przedstawienia poglądu ${ }^{30}$. Podobnych regulacji nie zawierają procedury: karna ${ }^{31}$ i sądowoadministracyjna ${ }^{32}$, dlatego też tak istotne jest, aby wszystkie niezbędne materiały w przypadku spraw rozpoznawanych we wskazanych trybach zostały załączone już do wniosku o wydanie istotnego poglądu ${ }^{33}$.

Ustawa nie określa kręgu podmiotów, które są legitymowane do złożenia wniosku o wydanie istotnego poglądu dla danej sprawy. Należy zatem uznać, że z wnioskiem może zwrócić się w zasadzie każdy ${ }^{34}$. W praktyce

${ }^{30}$ Istotne jest, że zgodnie z art. $63^{5} \S 2$ k.p.c. akta udostępniane są na wniosek Prezesa UOKiK jedynie w zakresie niezbędnym do przedstawienia poglądu. O tym, jaka część materiału sprawy zostanie udostępniona, decyduje zatem sąd (por. m.in. E. Rudkowska-Zbąszyk, Komentarz do art. $63^{5}$ Kodeksu postępowania cywilnego, w: Kodeks postępowania cywilnego. Komentarz, pod red. E. Marszałkowskiej-Krześ, Beck Online Komentarze, Legalis 2017). W praktyce może więc się okazać, że Prezesowi UOKiK nie zostanie udostępniona ta część materiału sprawy, która jest mu niezbędna do przedstawienia poglądu.

${ }^{31}$ Ustawa z dnia 6 VI 1997 r. Kodeks postępowania karnego (tekst jedn. Dz.U. 2017, poz. 1904 ze zm., dalej "k.p.k.").

32 Ustawa z dnia 30 VIII 2002 r. Prawo o postępowaniu przed sądami administracyjnymi (tekst jedn. Dz.U. 2017, poz. 1369 ze zm., dalej „p.p.s.a.”).

${ }^{33}$ Zasadny wydaje się postulat de lege ferenda uzupełnienia zarówno procedury karnej, jak i sądowoadministracyjnej w tym zakresie, zwłaszcza że brak dostępu do akt postępowania wyklucza w praktyce wydanie z urzędu istotnego dla sprawy poglądu (tj. w sytuacji, gdy nie wpłynie wniosek uczestnika postępowania bądź sądu w tym zakresie).

${ }^{34} \mathrm{~W}$ literaturze przedmiotu podjęte zostały próby zawężenia kręgu podmiotów legitymowanych do złożenia wniosku o wydanie przez Prezesa UOKiK poglądu istotnego dla 
inicjatywa wydania poglądu najczęściej wychodzi od stron toczącej się sprawy sądowej ${ }^{35}$. W tym zakresie wniosek o wydanie poglądu zazwyczaj jest kierowany przez zainteresowaną stronę bezpośrednio do Prezesa UOKiK. Za dopuszczalne w tym zakresie należy również uznać pośrednictwo sądu, przed którym dana sprawa jest prowadzona. Zastosowanie znajduje tu bowiem art. $187 \S 2$ k.p.c., zgodnie z którym pozew może zawierać wnioski służące rozpoznaniu sprawy ${ }^{36}$. Trzeba jednak zwrócić uwagę, że sąd nie ma obowiązku uwzględniać takiego wniosku strony ${ }^{37}$, przez co z praktycznego punktu widzenia zasadne wydaje się kierowanie wniosków o wydanie poglądu bezpośrednio do Prezesa UOKiK.

W świetle art. 31d u.o.k.k. nie może budzić wątpliwości, że wniosek o wydanie przez Prezesa UOKiK poglądu może złożyć sam sąd, przed którym dana sprawa się toczy ${ }^{38}$. Podejmowanie tego typu inicjatywy przez sądy należy ocenić pozytywnie, zważywszy na cele, jakimi kierował się ustawodawca, wprowadzając omawianą instytucję do polskiego porządku prawnego ${ }^{39}$.

Prezes UOKiK, wydając pogląd, winien bazować na materiale dowodowym zgromadzonym w toku sprawy sądowej, w tym udostępnionym

danej sprawy. J. Szczygieł (op. cit., s. 135) wskazuje, że ze stosownym wnioskiem do Prezesa UOKiK mogą zwrócić się strony, sąd i rzecznik konsumentów. Z kolei A. Piszcz (op. cit., s. 84) stoi na stanowisku, że inicjatywa w tym zakresie przysługuje wyłącznie sądom. Autorzy ci nie przedstawiają jednak szczegółowej argumentacji na poparcie swoich stanowisk.

${ }^{35}$ Por. m.in.: pogląd Prezesa UOKiK z 20 XII 2017 r. wydany dla sprawy XXIV C 657/17 toczącej się przed SO w Warszawie, sygn. RŁO-644-51/17/DL, https://uokik.gov.pl/ istotny_poglad_w_sprawie.php (dostęp: 21 I 2018); pogląd Prezesa UOKiK z 3 I 2018 r. wydany dla sprawy I C 361/17 toczącej się przed Sądem Rejonowym dla Warszawy Śródmieścia w Warszawie, sygn. RŁO-644-46/17/MM, https://uokik.gov.pl/istotny_poglad_w_sprawie.php (dostęp: 21 I 2018); pogląd Prezesa UOKiK z 29 XII 2017 r. wydany dla sprawy II C 730/17 toczącej się przed Sądem Rejonowym dla Warszawy-Woli w Warszawie, sygn. RKT-644-42/17/BP, https://uokik.gov.pl/istotny_poglad_w_sprawie. php (dostęp: 21 I 2018).

${ }^{36}$ Zob. J. Szczygieł, op. cit., s. 135. Por. również pogląd Prezesa UOKiK z 17 I 2018 r. wydany dla sprawy I C 839/17/M.B. toczącej się przed SO w Gdańsku, sygn. RŁO-64445/17/RB, https://uokik.gov.pl/istotny_poglad_w_sprawie.php (dostęp: 21 I 2018).

${ }^{37}$ Wydaje się, że decyzja w tym przedmiocie objęta jest zakresem dyskrecjonalnej władzy sądu.

${ }^{38}$ Podobnie: J. Szczygieł, op. cit., s. 135, oraz A. Piszcz, op. cit., s. 84. Zob. również pogląd Prezesa UOKiK z 22 XII 2017 r. wydany dla sprawy I C 876/17 toczącej się przed Sądem Rejonowym dla Warszawy Śródmieścia w Warszawie, sygn. RBG-644-27/17/DL, https://uokik.gov.pl/istotny_poglad_w_sprawie.php (dostęp: 21 I 2018).

${ }^{39}$ Jak zostało wskazane na wstępie, zgodnie z założeniami projektodawcy wspomniana instytucja miała na celu zapewnienie transferu wiedzy i doświadczeń z UOKiK do sądów powszechnych, Druk sejmowy nr 3662/VII kadencja z 10 VII 2015 r., s. 17. 
mu przez sąd w trybie art. $63^{5} \S 2$ k.p.c. oraz ewentualnie dostarczonym mu przez wnioskodawcę. Za niedopuszczalne wydaje się prowadzenie przez Prezesa UOKiK w celu wydania poglądu odrębnego postępowania dowodowego, które potencjalnie miałoby uzupełnić materiał dowodowy analizowanej sprawy sądowej. Należy zwrócić uwagę, że pogląd wydany na podstawie szerszego materiału aniżeli ten zgromadzony w toku sprawy sądowej mógłby stracić status dla niej istotnego. Dodatkowe dowody mogą bowiem rzutować na ocenę nie tylko określonego zagadnienia, ale i całej sprawy. W konsekwencji, jeżeli ocena zasadności wydania poglądu dla danej sprawy wymagałaby przeprowadzenia dodatkowych czynności dowodowych, Prezes UOKiK winien powstrzymać się od jego wydania. Nadto istotne jest, że w ramach obowiązujących procedur w sposób ścisły określono podmioty legitymowane do podejmowania poszczególnych czynności procesowych, w tym do podejmowania inicjatywy dowodowej ${ }^{40}$. Zatem, skoro Prezesowi UOKiK ustawodawca zakreślił kompetencję do przedstawienia dla sprawy poglądu, wnioskować należy, że nie przysługuje mu uprawnienie do podejmowania innych czynności procesowych, w tym do składania wniosków dowodowych.

Niezależnie od powyższego nie może ulegać wątpliwości, że Prezes UOKiK, wydając pogląd, winien uwzględniać całość posiadanej wiedzy i doświadczenia. Podstawą poglądu może być zatem zarówno wiedza posiadana przez niego z urzędu, jak i wiedza notoryjna, powszechna. Wydaje się, że korzystanie z tych zasobów informacji jest przy wydawaniu poglądu nie tylko dopuszczalne, ale i pożądane.

Artykuł 31d u.o.k.k. nie określa formy, w jakiej istotny dla sprawy pogląd winien być przez Prezesa UOKiK przedstawiony. W kontekście spraw sądowych, do których zastosowanie znajdzie procedura cywilna, doprecyzowanie $\mathrm{w}$ tym zakresie odnaleźć można w art. $63^{5} \S 1$ k.p.c. Przepis ten stanowi, że jeżeli przepisy odrębne przyznają określonym podmiotom, które nie uczestniczą w sprawie, uprawnienie do przedstawiania sądowi istotnego dla sprawy poglądu, do podmiotów tych stosuje

${ }^{40} \mathrm{~W}$ tym kontekście warto zwrócić uwagę na regulacje art. 61 i n. k.p.c., określające zasady udziału w procesie cywilnym organizacji pozarządowych. Organizacje te we wskazanych w art. 61 k.p.c. sprawach mogą wytaczać powództwa oraz przystępować do toczącego się postępowania. Występując w tak określonych rolach procesowych mogą podejmować w zasadzie wszelkie czynności procesowe (por. art. 61 k.p.c. oraz art. 62 $\S 2$ w zw. z art. 79 k.p.c.). Podobnych kompetencji nie mają natomiast, jeżeli zdecydują się na przedstawienie istotnego dla danej sprawy poglądu (zob. art. 63 k.p.c.). 
się odpowiednio przepis art. 63 k.p.c. określający zasadę, że pogląd taki winien mieć formę pisemną (pogląd winien być wyrażony w uchwale lub w oświadczeniu). Od powyżej wskazanej zasady w art. $63^{5} \S 1$ zd. 2 k.p.c. ustawodawca wprowadza jednak wyjątek, zgodnie z którym na wniosek podmiotu uprawnionego ( $w$ tym przypadku Prezesa UOKiK) sąd może zezwolić, aby pogląd został przedstawiony także ustnie na rozprawie.

Wydaje się, że wyżej opisana zasada pisemności poglądów, wobec braku stosownych regulacji w k.p.k. oraz p.p.s.a., na zasadzie analogii winna znaleźć zastosowanie do poglądów przedstawionych dla spraw karnych oraz sądowoadministracyjnych. Jednocześnie do sporządzanych pism zawierających istotne dla spraw poglądy zastosowanie znajdą określone w poszczególnych procedurach wymogi formalne dla pism procesowych $^{41}$.

\section{Charakter prawny istotnego poglądu Prezesa UOKiK}

W literaturze przedmiotu zdaje się nie budzić wątpliwości, że istotny pogląd wyrażony przez Prezesa UOKiK nie stanowi środka dowodowego $^{42}$. W ocenie autora ze stanowiskiem tym co do zasady należy się zgodzić. Nie stanowi on dowodu w tym sensie, że jego ewentualne wydanie dla danej sprawy nie prowadzi do wzbogacenia jej materiału dowodowego. W poglądzie przedstawiane jest jedynie stanowisko Prezesa UOKiK o określonej treści. Porównać je można do stanowiska uczestnika postępowania (strony, interwenienta itp.), stanowiska wyrażanego najczęściej w pismach procesowych, którego tezy winny być następnie przedmiotem postępowania dowodowego ${ }^{43}$. Różnica pomiędzy poglądem wyrażanym przez Prezesa UOKiK a stanowiskiem strony postępowania sądowego polega na tym, że pogląd Prezesa UOKiK stanowi obiektywną ocenę co do prawa lub faktów opartą na udostępnionym mu materiale ( $w$ tym materiale dowodowym) zgromadzonym

${ }^{41}$ Wymogi formalne pism procesowych zostały określone odpowiednio w art. 126 k.p.c., art. 119 k.p.k. oraz art. 46 p.p.s.a. Podobnie J. Szczygieł, op. cit., s. 137.

${ }^{42}$ Zob.: J. Szczygieł, op. cit., s. 136; A. Piszcz, op. cit., s. 85; M. Błachucki, op. cit., s. 755. Por. również: T. Misiuk, Udział organizacji społecznych w ochronie praw obywateli w postepowaniu cywilnym, Warszawa 1972, s. 241-249; A. Okleja, Organizacje społeczne ludu pracującego w świetle przepisów KPC, „Zeszyty Naukowe Uniwersytetu Jagiellońskiego. Prace Prawnicze" 1971, t. 260, nr 51, s. 192-193.

${ }^{43} \mathrm{~W}$ tym kontekście wydaje się, że istotny pogląd Prezesa UOKiK winien być zaliczony do niewładczych form działania administracji publicznej. 
$\mathrm{w}$ toku danej sprawy oraz na posiadanych przez niego z racji zajmowanego urzędu wiedzy i doświadczeniu. Natomiast stanowisko strony postępowania ma charakter subiektywny, dostosowany do przyjętej taktyki procesowej. Nadto, w przeciwieństwie do stanowiska strony postępowania, Prezesowi UOKiK nie przysługuje inicjatywa dowodowa. Wszelkie zatem powołane przez Prezesa UOKiK w poglądzie fakty, które nie były uprzednio przedmiotem dowodu, a które nie stanowią wiedzy notoryjnej, winny zostać potwierdzone w drodze odrębnych czynności dowodowych, podjętych z inicjatywy umocowanych do tego uczestników postępowania sądowego ${ }^{44}$.

W kontekście powyższego należy zwrócić uwagę na wyrok Sądu Okręgowego w Poznaniu z 1 czerwca 2017 r. ${ }^{45}$ W części poświęconej ustaleniu stanu faktycznego sprawy sąd wskazał, że oddalił „wniosek pozwanego o wezwanie Prezesa UOKiK do przedstawienia pisemnego poglądu istotnego dla sprawy [...], albowiem był to dowód zbędny dla rozstrzygnięcia (art. $217 \S 3 \mathrm{kpc}$ ) i zmierzałby do przedłużenia postępowania". W przytoczonym fragmencie dostrzec można niezasadność stanowiska sądu, który potraktował pogląd Prezesa UOKiK jako środek dowodowy. Z kolei dalszym tego skutkiem było oddalenie wniosku strony o przedstawienie istotnego poglądu przy całkowitym pominięciu przesłanek ustawowych z art. 31d u.o.k.k. i w konsekwencji przyjęcie w powołaniu się na art. 217 § 3 k.p.c., że pogląd byłby „zbędny dla rozstrzygnięcia [...] i zmierzałby do przedłużenia postępowania" 46 .

Od istotnego poglądu należy odróżnić dokument, w którym został on wyrażony. Pismo zawierające pogląd może bowiem stanowić dowód

\footnotetext{
${ }^{44}$ Por. M. Błachucki, op. cit., s. 755.

${ }^{45}$ Wyrok SO w Poznaniu z 1 VI 2017 r., sygn. XVIII C 94/17, Portal Orzeczeń Sądów Powszechnych (dostęp: 21 I 2018).

${ }^{46}$ Uderzający przy tym jest fakt potraktowania poglądu Prezesa UOKiK jako środka zmierzającego do obstrukcji postępowania, w sytuacji gdy jednym z elementów spornych toczącego się procesu była abuzywność klauzul znajdujących się w zawartej przez pozwanego umowie kredytu. Trzeba przy tym brać pod uwagę okoliczność, że obecnie Prezes UOKiK jest jedynym organem, który zgodnie z polskim ustawodawstwem uprawniony jest do orzekania w sposób abstrakcyjny o niedowolnym charakterze klauzul wzorców umownych stosowanych w relacjach z konsumentami. Nie sposób zatem podzielić stanowiska sądu w opisanej sprawie, że pogląd Prezesa UOKiK byłby dla niej całkowicie zbędny. Błędne stanowisko w opisanym zakresie wyraził również Sąd Rejonowy (SR) dla Warszawy-Mokotowa w Warszawie w wyroku z 30 VI 2017 r. (sygn. I C 793/16, niepubl.). Co znamienne, jako zbędny środek dowodowy w tym przypadku został uznany pogląd wydany dla tej konkretnej sprawy.
} 
tego, że Prezes UOKiK wydał dla danej sprawy pogląd o określonej w nim treści ${ }^{47}$. Wydaje się jednocześnie, że takiemu pismu, jako dowodowi przedkładanemu w toku odrębnego postępowania (w stosunku do tego, w którym został wydany), można przypisać cechy dokumentu urzędowego, bowiem jest on sporządzany w przepisanej formie oraz przez powołany do tego organ władzy publicznej w zakresie jego ustawowych kompetencji ${ }^{48}$.

W piśmiennictwie w kontekście art. 31d u.o.k.k. wskazuje się, że pogląd Prezesa UOKiK może dotyczyć i kwestii prawnych, i faktycznych ${ }^{49}$. Wydaje się jednocześnie, że wydawany przez Prezesa Urzędu pogląd może mieć charakter zarówno indywidualny (odnosić się do okoliczności konkretnej sprawy), jak i ogólny (wyrażać generalną opinię, np. w zakresie wykładni danego przepisu, która może znaleźć zastosowanie w wielu niezależnych od siebie sprawach sądowych). Należy podkreślić, że zgodnie z art. 31d u.o.k.k. pogląd ma być istotny dla sprawy. Z punktu widzenia tego przepisu nie ma zatem znaczenia, czy pogląd ma indywidualny czy ogólny charakter. Ważne jest, by stanowisko w nim wyrażone miało istotne znaczenie dla tej konkretnej sprawy. Nie może przy tym budzić wątpliwości, że to od okoliczności sprawy będzie zależało, czy znaczenie dla niej będzie miała ocena Prezesa UOKiK przeprowadzona w kontekście towarzyszących jej okoliczności czy też wyłącznie ocena dotycząca zagadnień o charakterze ogólnym, mogąca znaleźć zastosowanie do sprawy niezależnie od jej stanu faktycznego.

${ }^{47}$ Por. wyrok SO w Olsztynie z 31 III 2017 r. (sygn. I C 419/16, Portal Orzeczeń Sądów Powszechnych, dostęp: 21 I 2018), w którym sąd powołał się na pojęcie kredytu indeksowanego zawarte $\mathrm{w}$ dotychczas wydanych poglądach udostępnionych na stronach internetowych Urzędu.

${ }^{48}$ Por. art. 244 k.p.c. Odmiennie SR dla Warszawy-Mokotowa w Warszawie w wyroku z 30 VI 2017 r. (sygn. I C 793/16, niepubl.), który uznał pogląd Prezesa UOKiK za dokument prywatny.

${ }^{49}$ Odmienne stanowisko na tle regulacji odnoszących się do istotnych poglądów organizacji społecznych prezentują M. Piekarski (Przedstawienie przez organizację społeczna ludu pracujacego sądowi w postępowaniu cywilnym poglądu istotnego dla sprawy, "Państwo i Prawo" 1967, z. 4-5, s. 756) oraz M. Bernatt (Opinia przyjaciela sądu (amicus curiae) jako pomocnicza instytucja prawna w orzecznictwie sądów polskich, w: Sprawny sąd. Zbiór dobrych praktyk, cz. 2, pod red. Ł. Bojarskiego, Warszawa 2008, s. 189). W ocenie tych autorów pogląd nie może zawierać oceny stanu faktycznego. Zakładają oni przy tym, że pogląd może mieć jedynie ogólny charakter. Ze stanowiskiem tym nie sposób się jednak zgodzić. Za kluczową uznać tu należy przesłankę istotności dla sprawy, która determinuje charakter wydawanego poglądu (pogląd powinien dotyczyć oceny dowodów zgromadzonych w toku sprawy). Por. również T. Misiuk, Zadania organizacji społecznych w sądowym postępowaniu cywilnym, „Państwo i Prawo” 1966, z. 9, s. 311. 


\section{Zasady rozpatrywania poglądu Prezesa UOKiK przez sąd i konsekwencje jego pominięcia}

Analiza dotychczasowego orzecznictwa sądów powszechnych w zakresie wyroków w sprawach, w których Prezes UOKiK przedstawiał istotny pogląd, prowadzi do niepokojących wniosków. Nie chodzi przy tym o ocenę treści wydawanych poglądów, w których sądy są niezależne i niezawisłe. Należy jednak zwrócić uwagę na fakt, że sądy przy wydawaniu wyroków całkowicie pomijają wydany dla rozpoznawanej sprawy istotny pogląd Prezesa UOKiK. W uzasadnieniach licznych wyroków próżno szukać choćby wzmianki o tym, że Prezes UOKiK przedstawił pogląd dla danej sprawy ${ }^{50}$, a jeśli nawet wzmianka o poglądzie pojawia się w uzasadnieniu wyroku, to i tak sądy błędnie traktują go jako środek dowodowy, jednocześnie pomijając jako zbędny dla rozstrzygnięcia sprawy $^{51}$.

W kontekście celu, jakim kierował się ustawodawca, wprowadzając omawianą instytucję do u.o.k.k., wskazane wyżej podejście sądów do wydawanych przez Prezesa UOKiK istotnych poglądów wydaje się nie do zaakceptowania, niweczy bowiem rolę istotnego poglądu $\mathrm{w}$ rozstrzygnięciu sprawy.

${ }^{50}$ Por. pogląd Prezesa UOKiK z 4 I 2017 r. wydany dla sprawy I ACa 387/16 toczącej się przed Sądem Apelacyjnym (SA) w Szczecinie, sygn. DDK-644-538/16/GW, https:// uokik.gov.pl/istotny_poglad_w_sprawie.php (dostęp: 21 I 2018), łącznie z wyrokiem SA w Szczecinie z 1 II 2017 r., sygn. I ACa 387/16, niepubl.; pogląd Prezesa UOKiK z 18 XI 2016 r. wydany dla sprawy V Ca 174/16 toczącej się przed SO w Warszawie, sygn. RKT644-503/16/SB, https://uokik.gov.pl/istotny_poglad_w_sprawie.php (dostęp: 21 I 2018), łącznie z wyrokiem SO w Warszawie z 23 XI 2016 r., sygn. V Ca 174/16, Portal Orzeczeń Sądów Powszechnych (dostęp: 21 I 2018); pogląd Prezesa UOKiK z 8 IX 2017 r. wydany dla sprawy XVIII C 293/17 toczącej się przed SO w Poznaniu, sygn. RPZ-644-19/17/ AM, https://uokik.gov.pl/istotny_poglad_w_sprawie.php (dostęp: 21 I 2018), łącznie z wyrokiem SO w Poznaniu z 17 X 2017 r., sygn. XVIII C 293/17, Portal Orzeczeń Sądów Powszechnych (dostęp: 21 I 2018); pogląd Prezesa UOKiK z 10 XI 2016 r. wydany dla sprawy XXVII Ca 3477/16 toczącej się przed SO w Warszawie, sygn. RPZ-644-502/16/PG, https://uokik.gov.pl/istotny_poglad_w_sprawie.php (dostęp: 21 I 2018), łącznie z wyrokiem SO w Warszawie z 22 VI 2017 r., sygn. XXVII Ca 3477/16, niepubl.; pogląd Prezesa UOKiK z 27 XII 2016 r. wydany dla sprawy I C 489/16 toczącej się przed SO w Warszawie, sygn. RPZ-644-503/16/PG, https://uokik.gov.pl/istotny_poglad_w_sprawie.php (dostęp: 21 I 2018), łącznie z wyrokiem SO w Warszawie z 7 II 2017 r., sygn. I C 489/16, Portal Orzeczeń Sądów Powszechnych (dostęp: 21 I 2018).

${ }^{51}$ SR dla Warszawy-Mokotowa w Warszawie w wyroku z 30 VI 2017 r. (sygn. I C 793/16, niepubl.) uznał, że pogląd stanowi jedynie dokument prywatny nieistotny dla rozstrzygnięcia sprawy. 
W tym miejscu należy podkreślić, że choć sądy w żadnym zakresie nie są związane wydanym przez Prezesa UOKiK poglądem ${ }^{52}$, to w przypadku jego wydania dla danej sprawy zobligowane są ustosunkować się do niego i dać temu wyraz w uzasadnieniu ${ }^{53}$. Jednocześnie należy się zgodzić ze stanowiskiem, że obowiązek ten wynika z konieczności uwzględniania przez sądy przy rozstrzyganiu sprawy całości materiału zgromadzonego w jej toku. W tym miejscu zasadne wydaje się przytoczenie stanowiska T. Misiuk, która wskazała w kontekście istotnych poglądów wydawanych przez organizacje społeczne, że "[p]ogląd przedstawiony [...] w toku postępowania wchodzi w skład materiału sprawy i jeśli materiał ten mógł wpływać na rozstrzygnięcie sprawy (tj. jeśli sąd podzielił pogląd [...] w całości lub w części), to powinno to znaleźć wyraz w uzasadnieniu orzeczenia. Będzie to w szczególności niezbędne z punktu widzenia późniejszej kontroli rozstrzygnięcia przez sądy wyższej instancji. Kontrola ta wymaga, aby można było ustalić, czy i w jaki sposób sąd orzekający zużytkował pogląd [...] i w jakim stopniu pogląd ten wpłynął na rozstrzygnięcie sprawy. [...] Również wychowawcza rola orzeczeń sądowych wymaga ustosunkowania się przez sąd do poglądu [...] w uzasadnieniu wyroku"54.

W świetle aktualnego orzecznictwa nadzieję na zmianę podejścia sądów do poglądów wydawanych przez Prezesa UOKiK daje wyrok Sądu Apelacyjnego w Warszawie z 13 grudnia $2017 \mathrm{r} .{ }^{55} \mathrm{~W}$ ustnych motywach rozstrzygnięcia wydawanego wyroku sąd ten nie tylko zwrócił uwagę na przedstawione dla tej sprawy stanowisko Prezesa UOKiK, ale także szeroko się do niego ustosunkował. Tym bardziej należy pozytywnie ocenić, że Sąd Apelacyjny orzekał w tym przypadku w trybie abstrakcyjnej kontroli wzorców umownych, a zatem w zakresie przejętej w 2016 r. przez Prezesa UOKiK od Sądu Ochrony Konkurencji i Konsumentów kompetencji ${ }^{56}$.

${ }^{52}$ Zob.: J. Szczygieł, op. cit., s. 137; A. Piszcz, op. cit., s. 85; M. Błachucki, op. cit., s. 755.

${ }^{53}$ Zob. M. Bernatt, op. cit., s. 186, oraz literatura tam powołana.

${ }^{54}$ Tak T. Misiuk, Udział..., s. 248-249.

${ }^{55}$ Wyrok SA w Warszawie z 13 XII 2017 r., sygn. VII ACa 1036/17 (niepubl.).

${ }^{56}$ Zob. komunikat z 20 XII 2017 r. zatytułowany Sąd Apelacyjny uznał za niedozwolone postanowienia we wzorcu umowy mBank S.A. zamieszczony na stronie https://finanse. uokik.gov.pl/chf/kalendarium/sad-apelacyjny-uznal-za-niedozwolone-postanowienia-we-wzorcu-umowy-mbank-s.a. (dostęp: 21 I 2018). Por. również pogląd Prezesa UOKiK z 6 IV 2017 r. wydany dla sprawy VI ACa 1752/16 toczącej się w chwili wydania poglądu przed SA w Warszawie, sygn. RPZ-644-501/16/PG, https://uokik.gov.pl/istotny_poglad_w_sprawie.php (dostęp: 21 I 2018). 
W świetle art. 31d u.o.k.k. wydaje się również, że sądy nie są uprawnione do badania wydawanych przez Prezesa UOKiK poglądów pod względem spełnienia przez nie przesłanek określonych w tej regulacji. Za trafny uznać należy wniosek, że wyłączne kompetencje w tym zakresie ustawa przyznaje Prezesowi UOKiK. Absurdalna byłaby wszak konkluzja, że sądy każdorazowo są uprawnione do weryfikowania, czy pogląd został wydany w toku toczącej się przed nimi sprawy. Zgodnie $\mathrm{z}$ art. 31d u.o.k.k. w gestii Prezesa UOKiK jest w tym przypadku ocena występowania interesu publicznego przemawiającego za przedstawieniem dla sprawy poglądu, inne zatem podmioty, w tym sądy będące adresatami poglądów, nie wydają się uprawnione do kwestionowania jego oceny w tym zakresie. Oczywiście, powyższe nie oznacza, że strony i sąd są przedstawionym poglądem w jakikolwiek sposób związane. Merytoryczna polemika ze stanowiskiem Prezesa UOKiK jest jak najbardziej dopuszczalna. Wyłączona wydaje się być w tym przypadku jedynie możliwość badania wydanego poglądu pod względem formalnego spełnienia przesłanek określonych w art. 31d u.o.k.k.

Powyższe konkluzje znajdują potwierdzenie, kiedy analizie podda się sytuację, gdy wniosek o wydanie poglądu wpływa bezpośrednio do Prezesa UOKiK lub decyduje się on na wydanie poglądu z urzędu. Prezes UOKiK zobligowany jest wówczas z mocy ustawy do weryfikacji istnienia przesłanek do wydania poglądu. Z kolei sąd, do którego kierowane jest stanowisko Prezesa UOKiK, co zostało wyższej wskazane, nie jest uprawniony do pominięcia poglądu jako takiego. Brak jest przy tym regulacji, które pozwalałyby sądowi na odrzucenie bądź zwrot poglądu ze względu na niespełnianie przez niego przesłanek ustawowych ${ }^{57}$.

W tym miejscu należy zwrócić uwagę, że w przypadku skierowania przez stronę postępowania sądowego wniosku w trybie art. $187 \S 2$ k.p.c. sąd niewątpliwie może odmówić jego uwzględnienia. Wydaje się, że ewentualna odmowa w tym zakresie winna być argumentowana przy uwzględnieniu przesłanek określonych w art. 31d u.o.k.k. Istotne jest jednak, że wówczas weryfikacji poddawany jest jedynie wniosek strony, nie zaś sam pogląd. Nie istnieją zatem żadne przeszkody, aby

${ }^{57}$ Nie sposób twierdzić, że do poglądów wydawanych przez Prezesa UOKiK zastosowanie znajdzie art. 207 § 3 k.p.c., wszak Prezes UOKiK nie jest stroną postępowania, dla którego wydaje pogląd. Nadto nie można poglądu traktować jako pisma przygotowawczego w rozumieniu tego przepisu. 
Prezes UOKiK, mimo oddalenia wniosku strony złożonego w trybie art. $187 \S 2$ k.p.c., wydał istotny dla sprawy pogląd, czyniąc to z urzędu lub w odpowiedzi na wniosek skierowany do niego bezpośrednio.

\section{Podsumowanie}

Analizując dotychczasowe funkcjonowanie instytucji istotnego poglądu Prezesa UOKiK, stwierdzić można, że pomimo niedoceniania jej przez sądy, trudno nie oprzeć się wrażeniu, że Prezes UOKiK w postępowaniach dotyczących spraw z zakresu ochrony konkurencji i konsumentów powinien odgrywać ważną rolę. Nie bez znaczenia dla tej instytucji jest bowiem odwołanie się przez projektodawcę do jego wiedzy i doświadczenia.

Analiza dotychczasowego, jak na razie stosunkowo skąpego, orzecznictwa pozwala twierdzić, że wydawane przez Prezesa UOKiK poglądy w konkretnych sprawach bywaja przez sądy w sposób całkowity pomijane. W uzasadnieniach wyroków w sprawach, w których wydano istotny dla sprawy pogląd, często brakuje nawet wzmianki o podjętej przez Prezesa UOKiK inicjatywie, nie mówiąc już o merytorycznej polemice z jego stanowiskiem w sprawie. Wydaje się, że wyżej opisana sytuacja będzie mogła ulec zmianie jedynie w przypadku powszechnego przyjęcia, że poglądy wydawane przez Prezesa UOKiK nie są środkiem dowodowym mającym na celu uzupełnienie materiału dowodowego sprawy, ale stanowią obiektywne opinie "przyjaciela sądu” i zmierzają do poszerzenia wiedzy sądu o sprawy, które należą do zadań organu administracji od wielu lat.

Istotną rolę w zakresie kształtowania tej instytucji odgrywa niewątpliwie praktyka Prezesa UOKiK i jego podejście do wpływających wniosków o wydanie przez niego poglądu. Ważne jest, aby każdorazowo przedstawienie poglądu poprzedzała wnikliwa analiza przesłanek określonych $\mathrm{w}$ art. 31d u.o.k.k. Kluczowe jest przy tym to, aby poglądy były wydawane jedynie w zakresie zagadnień o istotnym znaczeniu dla toczących się przed sądami spraw, przy każdorazowym zidentyfikowaniu oraz zważeniu przemawiającego za wydaniem poglądu interesu publicznego.

Jednocześnie należy podkreślić, że w omawianej instytucji tkwi ogromny potencjał. Przy właściwym zastosowaniu może ona stać się, z korzyścią dla wszystkich uczestników rynku, dobrą platformą wymiany wiedzy i doświadczeń pomiędzy sądami a Prezesem UOKiK, w tym sprzyjać zbliżaniu ich stanowisk w zakresie wykładni obowiązującego 
prawa. Niewątpliwie, dla osiągnięcia tego celu niezbędne byłoby uzupełnienie procedur o przepisy regulujące zasady przedstawiania poglądów Prezesa UOKiK sądom administracyjnym i powszechnym w zakresie spraw karnych. Szczególnie istotne jest tu uregulowanie zasad udostępniania Prezesowi UOKiK materiałów zgromadzonych w aktach spraw sądowych. Zasadne byłoby również uzupełnienie wskazanej wyżej luki prawnej Rozporządzenia i doprecyzowanie zasad określających zakres zadań powierzonych delegaturom $w$ ramach tej instytucji. Wydaje się bowiem, że jedynie wyjaśnienie wszelkich wątpliwości prawnych w zakresie jej stosowania pozwoli na pełną realizację założonych przez ustawodawcę celów.

\section{OBSERVATIONS OF THE PRESIDENT OF THE OFFICE OF COMPETITION AND CONSUMER PROTECTION IN NATIONAL COURT PROCEEDINGS}

\section{S u m m a ry}

This article concerns the legal institution of observations submitted in civil proceedings by the President of the Office of Competition and Consumer Protection (hereinafter: President of the UOKiK). This institution is analysed within the framework of the hitherto practice of the Polish courts and the President of the UOKiK. Significant legal issues linked with the submission of the said observations and the way they are processed by the courts are presented, and premises for submitting these observations by the President of the UOKiK described. It is pointed out that submitting an observation is contingent upon the existence of public interest as well as occurrence of a significant question which is relevant to the case. Such a question needs to deal with the widely understood protection of competition and consumers. It is also noted that observations may only be submitted with regard to an actual case heard by the court. It may be addressed to either general, administrative or arbitration courts as well as to the Supreme Court. The article contains a description of the procedure of submitting observations, taking into account the settled practice of the President of the UOKiK. Within that scope issues concerning an application for submitting observations and formal requirements that such observations need to satisfy are also discussed. Furthermore, an attempt is made to determine the legal character of the said institution, taking into account the views presented in caselaw and literature. In that context a possibility of qualifying these observations as evidence has been excluded. Finally, the principles that need to be adopted by the courts when they examine the observations are discussed and the fact that courts have no competence to verify the observations submitted by the President of the UOKiK in respect of formal requirements and conditions for submission is stressed.

Keywords: observations - the President of the UOKiK - amicus curie - competition protection - consumer protection 